\title{
RADIO-FREQUENCY THERMAL ABLATION OF LUNG CANCER UNDER EPIDURAL ANAESTHESIA: COMPARISON OF THE EFFECTIVENESS OF BLOCKS BETWEEN HIGHER AND MID-THORACIC LEVEL
}

\author{
MR Khandoker ${ }^{1}$, H Razwanul ${ }^{2}$, H Rashadul $^{3}$, AM Sarwar ${ }^{4}$, UH Shahera Khatun ${ }^{5}$
}

\begin{abstract}
:
Purpose of the investigation is to evaluate the effectiveness of high thoracic epidural block in comparison to mid-thoracic epidural during Radiofrequency ablation for lung cancer. 60 patients (38 male) were selected for epidural segmental block who were proposed for radiofrequency thermal ablation for lung cancer. Patients were randomly divided in 2 groups: Group-A, higher thoracic epidural group \& Group-B, mid-thoracic epidural group. Under all aseptic preparation 18 G Epidural catheter was inserted through 18 G epidural needle and 4-6 $\mathrm{ml}$ of $0.5 \%$ bupivacaine was used during anaesthesia. Extend of block was demarcated by pain prick. RFT probe was allowed to insert 30 minutes after anaesthesia. The heat rate, blood pressure, respiration, $\mathrm{SpO}_{2}$ and temperature were monitored continuously during the procedure. Excellent block was found in 21 cases of Group-A and 15 cases of Group-B. Anaesthesia was inadequate in two cases of Group-A, and in 5 cases of Group-B, So, Higher thoracic epidural technique is better than mid thoracic epidural.
\end{abstract}

\section{INTRODUCTION:}

Radio-frequency Thermal (RFT) ablation of the lung cancer can be performed by percutaneous insertion of electrode into the tumor mass under ultrasonic or C.T. guidance. This is a surgical technique in which a wide diameter probe termed as Le-veen multiple array needle electrode is inserted into the tumor mass through an incision in the chest wall ${ }^{1,2}$. Severe pain is experienced due to needle insertion and burning during RFT ablation ${ }^{4}$.
General anaesthesia in not suitable as communication is not always possible with patient, which may be required during the procedure.

The procedure can be done under regional anaesthesia. Any surgical manipulation in the chest wall even radical mystectomy or Thoracotomy is very well tolerated under epidural block $^{4}$. So, presence study was done to compare high thoracic epidural block with mid-thoracic epidural to find out the best anaesthetic technique for RFT of lung.

\section{METHODS AND MATERIALS:}

60 patients (38 male), aged between $45-75$ years were selected for thoracic epidural block who were proposed for Radio-frequency thermal ablation of lung cancer. The patients gave written informed consent for the study, which was approved by the research ethics committee, DMCH, Dhaka. Patients with severe cardio-respiratory impairment, hemorrhagic diathesis and known allergic to drugs were excluded from the study. These patients were randomly divided into two groups. In Group-A, 30 patients were selected for higher thoracic epidural (between $\mathrm{T}_{1}-\mathrm{T}_{4}$ ) and in group-B, another 30 patients were selected for midthoracic epidural $\left(\mathrm{T}_{5}-\mathrm{T}_{8}\right.$. In each patient, an intravenous access was established and preloaded with $500 \mathrm{ml}$ of Ringer's solution. Epidural block was performed with $18 \mathrm{G}$ epidural needle and $18 \mathrm{G}$ epidural catheter (B. Brown) was inserted through epidural needle. In group-A, catheter was placed between $\mathrm{T}_{1}-\mathrm{T}_{4}$ space and in group-B, catheter was placed between $\mathrm{T}_{5}-\mathrm{T}_{8}$ space. $0.5 \%$ Bupivacain of

1. Junior Consultant Dept. of Anesthesiology, DMCH

2. Associate Professor Dept. of Cardiac Surgery, BSMMU

3. Professor of Pulmonology, NICVD, Dhaka

4. Interventional Oncologist, American Super Specialized Hospital Limited, Bangladesh

6. Professor Dept. of Anesthesiology, DMCH 
4-6 $\mathrm{ml}$ was used for anaestheia. Extend of block was identified by pin prick. 30 minutes later, after proper positioning of the patients, RFT probe was allowed to insert percutaneously into the tumor mass of the lung. The patients were monitored for heart rate, blood pressure, $\mathrm{Sp}_{2}$, and body temperature. Oxygen was supplied by nasal cannula. The probe is connected to Radio-frequency machine and heat was produced between $80-100^{\circ}$ $\mathrm{C}$ which coagulate the tumor tissue.

\section{RESULT:}

Patient characteristics are presented in Table-I. The patients of each group were further divided depending on the patient's response to pin pick into excellent, moderate \& inadequate (Table-II).

Excellent block was found in 21 cases of group-A and 15 cases of group-B, where no supplementary drugs were required. Moderate block occurred in 7 cases of group-A and 9 cases of group-B, where local infiltration of anaesthetics was required to perform the RFT ablation.

Regional anaesthesia was inadequate in 2 cases of group-A and 5 cases of group-B, where both local infiltration and additional intravenous narcotic drugs were required (Table-II).

Table-I

Patient characteristics

\begin{tabular}{lcc}
\hline & $\begin{array}{c}\text { Group - A } \\
\text { (High thoracic } \\
\text { epidural) }\end{array}$ & $\begin{array}{c}\text { Group - B } \\
\text { (Low thoracic } \\
\text { epidural) }\end{array}$ \\
\hline Sex (M : F) & $20: 10$ & $18: 12$ \\
Age (Year) & $62.8 \pm 7.4(45-76)$ & $63.8 \pm 10.8(48.75)$ \\
Weight $(\mathrm{Kg})$ & $55.2 \pm 6.8$ & $57.7 \pm 9.2(42.65)$ \\
\hline
\end{tabular}

Table-II

Quality of block

\begin{tabular}{lcc}
\hline Quality of block & Group A & Group B \\
\hline Excellent block & 21 cases & 15 cases \\
Moderate type block & 7 cases & 9 cases \\
Inadequate block & 2 cases & 5 cases \\
\hline
\end{tabular}

Haemodynamic stability were similar in both groups. Mean arterial pressure (MAP) varies $<20 \%$ in both groups. In 46 patients heart rate were within normal rate. But bradycardia developed in 14 cases of both groups where patients were treated with Inj. Atropine. The cooperation of the patients are shown in the Table-III.

\section{Table-III}

Patients Co-operation during procedures

\begin{tabular}{lcc}
\hline Patients co-operation & Group-A & Group-B \\
\hline Fully co-operative & 21 cases & 17 cases \\
Restless after one hour & 7 cases & 9 cases \\
Restless \& un co-operative & 2 cases & 3 cases \\
\hline
\end{tabular}

\section{DISCUSSION}

Radio-frequency ablation (RFT) is a new technique where high energy radio-frequency wave is employed to destroy non-small cell lung cancer ${ }^{1}$. The procedure is painful due to heat production and needle insertion in the chest wall ${ }^{5}$. General anaesthesia can be used for this purpose but postoperative respiratory support may be required in some patients due to compromised lungs. Beside these, communication with patients may be required during RFT ablation. So, general anaesthesia is not absolutely suitable. Surgical intervention in the chest wall can be done by lumber epidural anaesthesia. But large quantities of local analgesic drugs are necessary to produce anaesthesia in the thoracic region ${ }^{5}$. The thoracic epidural block may be suitable alternative for this type of surgical intervention. One of the advantages of thoracic epidural block is that the area of analgesia is confined to the area of operation due to segmental block, thus minimizing the vaso-motor paralysis and subsequent fall of blood pressure. Higher epidural block may sometimes interfere sympathetic activity to the heart which may cause hypotension and bradycardia but effect is less with smaller dose of $0.5 \%$ Bupivacine. Dose of the Bupivacane $1.5 \mathrm{ml} /$ segment between the age of 50 to 65 years and $0.6-1 \mathrm{ml} /$ segment between 65 to 80 years of age may be used. A complete relief of pain improves diaphragmatic function, ventilation and prevents hypoxia even in abnormal position. The thoracic epidural block produces small reduction of cardiac output, heart rate, blood pressure and decreased myocardial oxygen demand and maintain the cardiovascular status in a relatively normotensive 
range ${ }^{6}$. When thoracic or abdominal pain limits the capacity to breathe, epidural anaesthesia clearly improves the vital capacity, functional residual capacity and the $\mathrm{PaO}_{2}$. Block of autonomic nerves does not cause bronchospasm as might be expected ${ }^{7}$. The thoracic epidural block is definitely cost effective for such procedure than that of general anaesthesia ${ }^{7}$.

\section{CONCLUSION:}

Radio-frequency thermal ablation of lung cancer under thoracic epidural block is new in Bangladesh. It is cost effective and safe technique. So, higher epidural segmental block is a suitable anaesthetic technique for this procedure where patient remain alert with adequate ventilatory function ${ }^{3}$.

\section{REFERENCES:}

1. Karasawa K, Muta N, Nakagowa K, et al. A thermo-radiotherapy in the treatment of locally advanced non-small cell lung cancer. International Journal of Radiation Oncology 1991; 30: 1171-1177.
2 Goldberg SN, Gazelle GS, et al. Tissue ablation with radio-frequency using multiprobe arrays. Academic Radiology 1995; 2: 670-674.

3. Goldberg S N, Gazelle G S, Helpern EF, et at. Radiofrequency tissue ablation: importance of local temperature along the electrode tip exposer in determining lesion shape and size. Aeademic Radiology 1996; 3: 212-218.

4. Neves YF, Brasher A,. Buckingham WWl. Epidural anesthesia in thoracic surgery: A preliminary report. Journal of Thoracic Surgery 1948; 17: 123.

5. Handolin H. Lathines J, Lansimees E, Tuppurainen T, Partanen K. The effect of thoracic epidural analgesia on respiratory function after cholecystectomy. Anaesthesiology 1987; 31: 645-651.

6. Raj PP, Umeshraya P, Michael SH. Practical management of Pain, $2^{\text {nd }}$ edition. Mosby Year book 1992; 766-767.

7. Johnstone RE, Martinec CL. Costs of Anaesthesia. Anesthesia and Analgesia 1993; 76: 840-848. 